\title{
Etiske utfordringer med nyere reproduksjonsteknologi
}

\author{
Bjorn Hofmann
}

Institutt for helsevitenskap, NTNU Gjøvik og Senter for medisinsk etikk, Universitetet i Oslo, bjoern.hofmann@ntnu.no

DOI: http://dx.doi.org/10.5324/eip.v11i2.2247

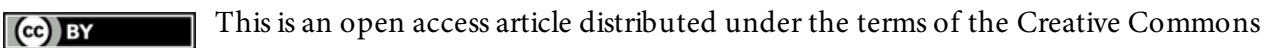
Attribution 4.0 International License, which permits unrestricted use, distribution, and reproduction in any medium, provided the original author and source are credited.

Moderne teknologi gir fantastiske muligheter for menneskelig formering. Mange som tidligere ikke kunne få barn, eller som fikk syke barn, kan nå hjelpes. Samtidig reiser mulighetene en rekke vanskelige moralske spørsmål, som ikke har enkle svar - ofte fordi de bunner i grunnleggende etiske motsetninger. Denne artikkelen gir en kort oversikt over de mulighetene som tre typer teknologier gir: assisterende, seleksjonsfremmende og egenskapsendrende teknologier. Deretter peker den på noen av de viktige moralske spørsmålene som disse teknologiene reiser $i$ betydningen «Hvordan bør teknologiene brukes»? Så stilles spørsmålet: Hvordan skal vi begrunne bruken? Dette spørsmålet peker på en rekke grunnleggende etiske utfordringer. Det er disse utfordringene som gjør at de moralske spørsmålene sjelden finner solide og stabile svar, men til stadighet blusser opp i til dels heftige offentlige debatter. I tillegg løfter artikkelen frem flere moralske spørsmål som er glemt eller gjemt. Spørsmålene som vi ikke stiller kan ofte fortelle oss like mye om oss selv og våre verdier, som de spørsmålene som drøftes eksplisitt. De moralske spørsmålene - samt de underliggende etiske utfordringene og de glemte spørsmålene - kan forklare hvorfor debattene ofte står på stedet hvil, og hva vi må jobbe med for å komme videre $i$ drøftingene av moderne reproduksjonsteknologi. Vi synes à voere teknologiske helter som er fremragende på teknikk, men elendige på etikk. Målet er å forhindre at vi blir tragiske helter som går til grunne på våre beste egenskaper.

Nøkkelord: reproduksjonsteknologi, assistert reproduksjon, invitro-fertilisering, fosterdiagnostikk, gen redigering, sortering, abort

English summary: Ethical challenges with newer reproductive technology

Modern technologies provide fascinating opportunities for human reproduction. Many persons previously infertile, or who risked having diseased children, can now have healthy children. At the same time, these technological opportunities also raise a wide range of moral questions, which rarely have easy answers. One reason for this is that they are based on profound ethical challenges. This article sets out to give a short overview of three types of technologies: assisting, selective, and characteristicchanging technologies. It goes on to highlight some of the important moral questions raised by these technologies. The third part addresses the basic ethical challenges lurking behind the moral questions and debates. The fourth part addresses some forgotten or hidden questions, arguing that these are telling and important. 
The article ends with arguing that many of the basic ethical challenges and the unaddressed questions can explain why debates on reproductive technologies are so heated and static. We appear to have become technological giants, but ethical infants. Accordingly, we should try to avoid becoming tragic heroes succumbing to our very best abilities.

Keywords: assistive reproductive technologies, invitro fertilization, prenatal testing, gene editing, expressivist objection, abortion

\section{Innledning}

Helt fra antikken har mennesket forsøkt å påvirke sitt avkom under og etter unnfangelsen, men aldri tidligere har muligheten til å gjøre det vært større enn nå. Moderne reproduksjonsteknologi har gitt oss fantastiske muligheter til å hjelpe mennesker som har vansker med å få barn og mennesker som har stor risiko for å få syke barn. I tillegg gir teknologien oss muligheter til å velge eller bestemme egenskapene til fremtidige barn.

Med mulighetene følger også en rekke spørsmål og vanskelige valg. Få former for helseteknologi er gjenstand for mer offentlig debatt og regulering. Debattene er ofte preget av sterke oppfatninger, klare grupperinger og manglende reell dialog (Baruch et al 1988; Cutas 2014). Samtidig har nye teknologier nå gitt oss banebrytende muligheter som gir behov for nyansering og nye grensedragninger. I tillegg er det viktig å stille spørsmålene som ikke kommer frem i det offentlige ordskiftet: de glemte eller skjulte spørsmålene.

I denne artikkelen vil jeg gi en kort oversikt over de mulighetene som dagens reproduksjonsteknologi gir. Deretter vil jeg peke på hvilke moralske spørsmål den reiser: Hva er det riktig å gjøre? Skal vi innføre teknologien? Hvis ja, hvordan? Dette er spørsmål vi som individer og samfunn må svare på gjennom lovgiving og praksis. Så vil jeg peke på hvorfor vi ofte sliter med å finne velbegrunnede og stabile svar på de moralske spørsmålene. Det vil jeg gjøre ved å peke på de etiske utfordringene som ligger under: det som gjør det vanskelig å begrunne de moralske valgene. ${ }^{1}$ Til sist vil jeg peke på noen av spørsmålene som synes oversett i debattene om moderne reproduksjonsteknologi og reflektere over hvorfor disse har fått så lite oppmerksomhet.

Hensikten er å øke bevisstheten om de vanskelige spørsmålene og viktige valgene vi har. Dette er viktig for en åpen offentlig debatt og en transparent beslutningsprosess i reguleringen av reproduksjonsteknologi. Det er også viktig for hvilken vei vi velger som menneskehet. Målet er å bringe vår etiske refleksjon mer på høyde med våre tekniske ferdigheter - og forhindre at vi blir tragiske helter som går til grunne på grunn av våre beste egenskaper (Fredriksen 2006), nettopp slik som Zapffe påpekte (Zappfe 1943/1996, §75,90-93).

\section{Muligheter}

Tilfanget av ulike former for teknologi brukt ved reproduksjon er enormt. Grovt sett kan man dele teknologiene i tre typer:

1. Assisterende teknologi. Dette er teknologi som assisterer eller erstatter eksisterende biologiske funksjoner, slik som inseminering og befruktning utenfor kroppen. 
2. Teknologier som gjør det mulig å selektere fostre på bakgrunn av egenskaper. Dette er ulike former for tester som utføres på kjønnsceller, befruktede egg eller fostre for så å velge ut de som skal settes inn, destrueres eller aborteres.

3. Teknologier som endrer grunnleggende egenskaper er teknologi som endrer arvematerialet, slik som cellenes DNA.

I tillegg kommer ulike former for donasjon (av spermier, egg, embryoer og deler av disse) og surrogati, som har egne utfordringer. Donasjon og surrogati trekkes her bare inn der det er relevant for å drøfte reproduksjonsteknologiene og deres utfordringer.

\section{Assisterende teknologier}

Inseminering har vært praktisert i Norden siden 1930-tallet, men assistert befruktning fikk først allmenn oppmerksomhet etter at Louise Brown ble født i 1978 (Steptoe 1978). Hun var den første som ble født ved hjelp av befruktning utenfor kroppen (in vitro fertilisering, IVF). Siden har mulighetene for assistert reproduksjon nærmest eksplodert. Vi har fătt en rekke forskjellige former for injeksjon av enkeltspermier i eggceller (Palermo 1992), eggdonasjon (Trounson 1983; Buster 1983), midlertidig nedfrysing av kjønnsceller og overtallige embryo (Trounson 1983), samt cytoplasmadonasjon (Cohen 1997). Og, som en følge av profesjonalisering, standardisering og industrialisering, blir de vanlige metodene for assistert befruktning stadig tryggere og mer effektive.

Ulike metoder for assistert reproduksjon, som i dag er i utstrakt bruk i mange land, er vist i tabell 1.

\section{Teknologifor seleksjon av kjonnsceller, befruktede egg og fostre}

En annen stor og viktig gruppe av teknologier gir informasjon om kjønnsceller, befruktede egg eller fostre slik at potensielle foreldre skal kunne ta informerte reproduktive valg. Den mest kjente og utbredte er fosterdiagnostikk. Ved hjelp av ulike tester, slik som ultralyd, blodprøver, fostervannsprøver og morkakeprøver, kan man med ulik grad av sikkerhet fastslå om fosteret har gitte egenskaper, for eksempel hvor mange kromosomer fosteret har. Der hvor disse biologiske egenskapene er assosiert med en uønsket tilstand eller sykdom, kan man velge å beholde eller fjerne fosteret. I det første tilfellet kan både vordende foreldre og helsepersonell forberede seg på det som kommer. I Norge brukes fosterdiagnostikk der hvor foreldre tidligere har fått barn med alvorlig sykdom (kromosomsykdom, nevralrørsdefekt, alvorlig kjønnsbunden sykdom) eller der det er økt risiko for slik sykdom, for eksempel på grunn av alder. Mest kjent er testingen for trisomi 21 (med tanke på Downs syndrom), trisomi 18 (for Edwards syndrom) og trisomi 13 (for Pataus syndrom).

En ny teknologi har gjort det mulig å analysere cellefritt DNA fra fosteret som finnes i kvinnens blod under graviditeten. Testen omtales gjerne som non-invasiv prenatal test (NIPT) og kan brukes til å undersøke helt spesifikke egenskaper hos fosteret, slik som trisomi 13, 18, og 21 og fosterets kjønn, men den kan i prinsippet brukes til å undersøke hele arvematerialet til fosteret (helgenomsekvensering). Testen er meget nøyaktig og kan tas før grensen til selvbestemt abort. Fordi det kan være vanskelig å avgrense hvilke tilstander man skal kunne teste for, anbefaler enkelte å tilby helgenomsekvensering av fosteret (Chen \& Wasserman, 2017). NIPT gir dermed helt nye muligheter til (fra)valg av fostre, men også til å forberede seg på 
hvilke genetiske egenskaper det kommende barnet vil ha (dersom fosteret ikke fjernes).

Tabell 1 Oversikt over ulike former for assisterende teknologier for reproduksjon som i dag er i bruk i mange land, med forkortelser og kort forklaring. Tabellen baserer seg på (Hofmann og Moldestad 2012).

\begin{tabular}{|l|l|l|}
\hline Teknologi, metode & Forkortelse & $\begin{array}{l}\text { Kort beskrivelse (innen assistert } \\
\text { reproduksjon) }\end{array}$ \\
\hline $\begin{array}{l}\text { Ektefelleinseminasjon } \\
\text { "Artificial insimination by } \\
\text { husband" }\end{array}$ & AIH & $\begin{array}{l}\text { Inseminasjonsbehandling med sæd } \\
\text { fra ektefelle eller samboer }\end{array}$ \\
\hline $\begin{array}{l}\text { Donorinseminasjon } \\
\text { "Artificial insimination by } \\
\text { donor" }\end{array}$ & AID & $\begin{array}{l}\text { Inseminasjonsbehandling med } \\
\text { donorsæd }\end{array}$ \\
\hline $\begin{array}{l}\text { Assistert befruktning } \\
\text { utenfor kroppen, } \\
\text { Invitrofertilisering }\end{array}$ & IVF & $\begin{array}{l}\text { Befruktning utenfor kroppen med } \\
\text { bruk av modne egg som er hentet ut } \\
\text { av kvinnen og sædceller. }\end{array}$ \\
\hline $\begin{array}{l}\text { Intracytoplasmatisk } \\
\text { spermieinjeksjon }\end{array}$ & ICSI & $\begin{array}{l}\text { IVF der en sædcelle blir ført inn i } \\
\text { hvert av de modne eggene med en } \\
\text { nål. }\end{array}$ \\
\hline $\begin{array}{l}\text { Perkutan epididymal } \\
\text { spermieaspirasjon }\end{array}$ & PESA & $\begin{array}{l}\text { Metode for uthenting av sædceller } \\
\text { fra bitestikler, som så brukes ved } \\
\text { ICSI. }\end{array}$ \\
\hline $\begin{array}{l}\text { Mikrokirurgisk epididymal } \\
\text { spermieaspirasjon. }\end{array}$ & MESA & $\begin{array}{l}\text { Metode for uthenting av sædceller } \\
\text { fra bitestikler, som deretter benyttes } \\
\text { til ICSI. }\end{array}$ \\
\hline $\begin{array}{l}\text { Testikulær spermieaspirasjon } \\
\text { replacement" }\end{array}$ & TESA & $\begin{array}{l}\text { Uthenting av spermier fra testikler } \\
\text { hos menn med azoospermi. Benyttes } \\
\text { i forbindelse med ICSI. }\end{array}$ \\
\hline Kryopreservering & $\begin{array}{l}\text { Overføring av cytoplasma fra en } \\
\text { eggcelle til en annen med den } \\
\text { hensikt å øke sjansen for graviditet. }\end{array}$ \\
\hline Cytoplasmadonasjon & $\begin{array}{l}\text { Frosset embryo fra tidligere } \\
\text { befruktning benyttes til IVF eller } \\
\text { ICSI }\end{array}$ \\
\hline Frozen embryo & $\begin{array}{l}\text { Nedfrysing og oppbevaring av } \\
\text { kjønnsceller og befruktede egg }\end{array}$ \\
\hline
\end{tabular}

En annen teknologi som er viktig for fravalg av befruktede egg og fostre er preimplantasjonsgenetisk diagnostikk (PGD). Ved PGD skjer befruktningen utenfor kroppen (IVF). Ved å ta ut en celle av det befruktede egget, etter at dette har delt seg noen få ganger, kan man, ved å analysere denne cellen, kartlegge viktige egenskaper hos fosteret. Metoden brukes der personer er bærere av alvorlig genetisk sykdom og det er stor fare for at sykdommen kan overføres til et kommende barn. Man velger bort og destruerer de befruktede eggene som vil gi sykdom og setter inn befruktede egg som ikke vil utvikle sykdommen. Denne teknologien kan også brukes når personene ikke har økt risiko for å få barn med sykdom. Da kalles den preimplantasjonsgenetisk screening (PGS). 
PGD og PGS gir samme valg som ved fosterdiagnostikk, men på et tidligere stadium. I tillegg forutsetter teknologien at man gjør IVF. Tabell 2 oppsummerer de viktigste former for teknologier som fremmer (fra)valg ved reproduksjon.

Tabell 2 Oversikt over ulike former for teknologier som fremmer seleksjon ved reproduksjon som i dag er i bruk i mange land, med forkortelser og kort forklaring.

\begin{tabular}{|l|l|l|}
\hline Teknologi, metode & Forkortelse & $\begin{array}{l}\text { Kort beskrivelse (innen assistert } \\
\text { reproduksjon) }\end{array}$ \\
\hline Ultralyd & ULD & $\begin{array}{l}\text { Ultralyd som kan beskrive anatomiske } \\
\text { forhold ved fostre og brukes til å beregne } \\
\text { risiko for sykdom. }\end{array}$ \\
\hline Blodprøve & BT & $\begin{array}{l}\text { Analyse av kvinnens blod som brukes til å } \\
\text { beregne risiko for sykdom hos det } \\
\text { fremtidige barnet. }\end{array}$ \\
\hline $\begin{array}{l}\text { Kombinasjon av tidlig } \\
\text { ultralyd og blodprøve }\end{array}$ & KUB & $\begin{array}{l}\text { Kombinasjon av ULD og BT for å redusere } \\
\text { usikkerheten i risikoberegningene. }\end{array}$ \\
\hline $\begin{array}{l}\text { Fostervannsprøve } \\
\text { (amniocentese) }\end{array}$ & AC & $\begin{array}{l}\text { Invasiv prøve der man gjennom en nål } \\
\text { trekker ut litt forstervann som analyseres } \\
\text { for å beregne risiko for sykdom hos det } \\
\text { fremtidige barnet. }\end{array}$ \\
\hline $\begin{array}{l}\text { Morkakeprøve } \\
\text { (chorionbiopsi) }\end{array}$ & CB & $\begin{array}{l}\text { Invasiv prøve der man gjennom en nål tar } \\
\text { prøve av morkaken som analyseres for å } \\
\text { beregne risiko for sykdom hos det } \\
\text { fremtidige barnet. }\end{array}$ \\
\hline $\begin{array}{l}\text { Ikke-invasiv prenatal } \\
\text { test, } \\
\text { (non-invasive prenatal }\end{array}$ & NIPT & $\begin{array}{l}\text { Analyse av celle-fritt føtalt DNA i morens } \\
\text { blod for å beregne risiko for sykdom hos } \\
\text { det fremtidige barnet. }\end{array}$ \\
\hline
\end{tabular}

\section{Teknologier som endrer grunnleggende egenskaper}

I tillegg til metoder for å assistere reproduksjon og til å selektere fostre, har vi nylig fått flere metoder som gjør det mulig å endre egenskapene til fostre og kjønnsceller. Mitokondriedonasjon er teknologien som har kommet lengst. Metoden brukes for å hindre overføring av ulike mitokondriesykdommer fra mor til datter. Det gjøres ved å bruke et kjerneløst egg fra en annen kvinne, sammen med cellekjernen fra egget til kvinnen med sykdommen og sæd fra denne kvinnens mann (eller donor). Mitokondriene inneholder DNA, og barnet som fødes vil ha mitokondrielt DNA fra kvinnen som donerte egget der kjernen ble fjernet. Dette har vært vellykket gjennomført på aper (Macaca mulatta) (Tachibana 2009) og er nylig tillatt brukt for mennesker i Storbritannia. Vellykket mitokondriedonasjon er også nylig rapportert hos mennesker i Mexico (Hamzelou 2016; Zhang 2016). Man ser for seg at denne og lignende metoder vil utvide de reproduktive mulighetene til mange som har eller er bærere av alvorlige sykdommer, og bidra til å unngå at det blir født barn med slike sykdommer.

En av de mest interessante nye mulighetene er å lage humane kjønnsceller basert på induserte pluripotente stamceller (iPSC) (Takahashi 2006; Cutas 2014) hentet fra pasientene selv. Man har nylig vist at embryonale stamceller (ES) fra mus og mennesker kan differensieres til opprinnelige kjønnsceller (PGC) og kjønnsceller in 
vitro (Toyooka 2003; Hübner 2003; Clark 2010; Mouca 2016) og at de kan gi opphav til levende avkom i mus (Nayernia 2006; Ohinata 2009).

Tabell 3 Ulike former for assistert reproduksjon basert på endring av celler eller cellers innhold.

\begin{tabular}{|c|c|c|}
\hline Mitokondriedonasjon & $\mathrm{MST} / \mathrm{PNT}$ & $\begin{array}{l}\text { Overføring av maternell spindle eller } \\
\text { pronukleoner fra en eggcelle/embryo } \\
\text { til en annen eggcelle. }\end{array}$ \\
\hline $\begin{array}{l}\text { In vitro gametogenese } \\
\text { ved hjelp av induserte } \\
\text { pluripotente stamceller }\end{array}$ & $\begin{array}{l}\text { IVG ved hjelp } \\
\text { av iPSC }\end{array}$ & $\begin{array}{l}\text { Produksjon av kjønnsceller fra } \\
\text { omprogrammerte kroppsceller. }\end{array}$ \\
\hline Genredigering & CRISPR Cas9 & $\begin{array}{l}\text { En molekylær «saks», som gjør det } \\
\text { mulig å lage målrettede endringer i } \\
\text { arvestoffet i alle celletyper i alle } \\
\text { levende organismer. }\end{array}$ \\
\hline Gendrivere & GD & $\begin{array}{l}\text { Genetiske elementer som kan } \\
\text { overstyre de vanlige arvebetingelsene } \\
\text { og øker sannsynligheten for at de selv } \\
\text { går i arv fra forelder til avkom. Lages } \\
\text { ved å sette CRISPR/Cas9-systemet inn } \\
\text { i arvestoffet sammen med den } \\
\text { ønskede genvarianten. }\end{array}$ \\
\hline Kloning ${ }^{*}$ & $\mathrm{RC}$ & $\begin{array}{l}\text { Fremstilling av embryo fra } \\
\text { kroppsceller }\end{array}$ \\
\hline
\end{tabular}

* Det har vært vanlig å bruke betegnelsen «reproduktiv kloning», men blant annet WHO har påpekt kloning dreier seg om replikasjon og ikke reproduksjon.

Noen av mulighetene for reproduksjon med endring av arveegenskapene er vist i figur 1 .

Man kan altså bruke kroppsceller, slik som hudceller, til å produsere kjønnsceller (Takahashi 2007). Bruk av iPSC kan dermed gi opphav til helt nye reproduksjonsstrategier (Whittaker 2007). Infertile menn og kvinner vil kunne få laget sperma og eggceller fra egne somatiske celler, slik at de kan få avkom med genetisk materiale fra dem selv. Mannlige par vil også kunne få laget sperma og eggceller fra egne somatiske celler (fordi de har både X-og Y-kromosomer), slik at begge partene i parforholdet bidrar genetisk til et felles avkom (Whittaker 2007; Deng 2010; Hermerén 2010) ${ }^{2}$. I prinsippet kan sperma og eggceller utvikles fra det samme individet (Nagano 2007; Eggan 2002; Hendriks 2015). Enkelte antar at selvbefruktning innebærer en stor genetisk risiko (Whittaker 2007), men det er født mus av to fedre, og man har stor tro på at selv-formering er mulig (Cutas 2016).

I tillegg har man nylig fått metoder som kan redigere direkte på DNAsekvensene i cellekjernen. Dette gjør det mulig å endre defekte og fjerne uønskede gener. Selv om man antar at det vil ta tid før dette kan anvendes i menneskelig reproduksjon, er det allerede rapportert om kinesiske forskere som har endret DNA (CCR5-genet) for å gjøre fostret motstandsdyktig mot HIV (Regalado, 2016) og amerikanske forskere har klart å fjerne sykdomsgenet for en hjertesykdom i embryoer (Ma 2017). Genredigering gir derved uante muligheter for å forhindre 
sykdom hos fremtidige barn, men også til å endre arvematerialet hos disse i tråd med spesifikke ønsker hos foreldrene eller andre.

Figur 1 Ulike muligheter for å redigere i kjønnscellenes arvemateriale ved menneskelig reproduksjon. Figuren stammer fra (Vassena 2016).

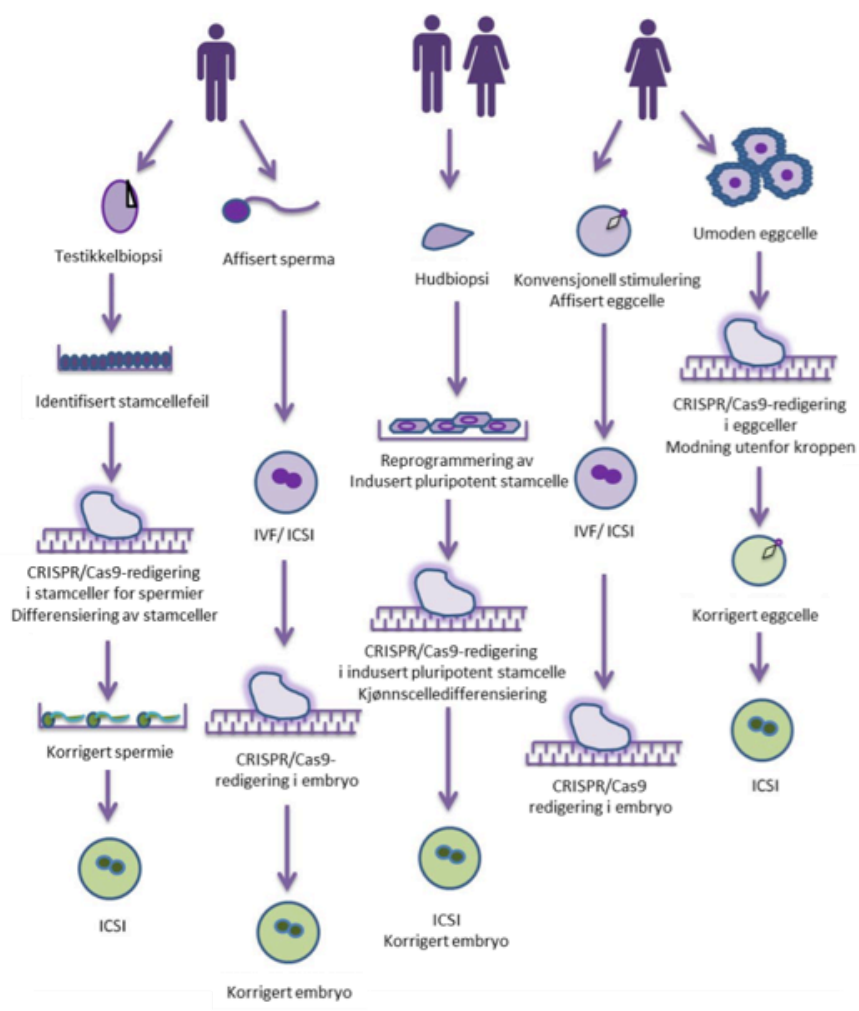

Ytterligere en teknologi kan komme til å få betydning innen reproduksjon: gendrivere. Gendrivere er såkalte 'egoistiske' genetiske elementer som kan overstyre de vanlige vilkårene for arv. De øker sannsynligheten for at de selv går i arv fra forelder til avkom. Gendrivere kan lages ved å sette CRISPR/Cas9-systemet inn i arvestoffet sammen med den ønskede genvarianten. Den molekylære «saksen» vil også kutte tilsvarende gen på kromosomet som er arvet fra den andre forelderen ,slik at den sørger den for raskere spredning enn ellers. Gendrivere gir (g)enestående muligheter til å fremme utbredelsen av gener, men fordi mennesker har en senere forplantning enn mange andre organismer, forventes foreløpig liten anvendelse av gendrivere innen menneskelig reproduksjon.

Vi har med andre ord fått mange teknologiske muligheter - muligheter som var utenkelige for få år siden. Vi har på ett vis blitt teknologiske helter. Spørsmålet er hvordan vi hån dterer de vanskelige valgene mulighetene gir. Er vi etiske helter også? Eller er vi etiske pygmeer? De omtalte teknologiene reiser en rekke moralske spørsmål om hva som er riktig å gjøre. La oss se på de viktigste spørsmålene, før vi ser på de etiske utfordringene som gjør det vanskelig å besvare dem.

\section{Hva skal vi gjøre? Reproduksjonsteknologiens moralske sporsmål}

Hvilke moralske spørsmål følger av reproduksjonsteknologiene beskrevet ovenfor? 


\section{Assisterende teknologier}

Allerede det første barnet født med IVF (Louise Brown, 1978) skapte heftige debatter. Det mest fremtredende spørsmålet var hvorvidt det er riktig «å gripe inn i naturen». For enkelte var en slik inngripen det samme som «å leke Gud» mens det for andre var «å tukle med» en finstemt naturgitt balanse. Betegnelsene som ble brukt i den første debatten viser tydelig hvordan man så teknologien som en inngripen i det naturlige: «kunstig befruktning», «prøverør», «manipulering av naturen» og «inngripen i skaperverket» er bare noen eksempler.

Et annet moralsk spørsmål var også sentralt: Hvordan kan vi hjelpe mennesker som av ulike grunner ellers ikke kan få (friske) barn? Teknologien ga etter hvert mange svar på dette spørsmålet, og med svarene dukket det opp nye spørsmål. Hvor effektive og sikre er de ulike metodene? Skader de kvinne eller barn? Hvor mange forsøk (med IVF) er det rimelig at hver kvinne får? Hvor gamle kan kvinnene være før det ikke er kostnadseffektivt (med IVF)? Hvor mange befruktede egg skal det settes inn (på grunn av økt risiko ved flerlingesvangerskap)? Når er det riktig å redusere antall fostre? Hva skal gjøres med (nedfrossede) kjønnsceller og befruktede egg? Hvem eier disse (der parene går fra hverandre)? Kan man bruke kjønnsceller eller embryoer fra avdøde personer (for å gi søsken til allerede eksisterende barn)? Hvilke krav skal stilles til personer som skal få hjelp til å bli foreldre? Dette er moralske spørsmål som i lov og praksis har funnet sine svar, men som med jevne mellomrom dukker opp (igjen) i det offentlige ordskiftet.

En av grunnene til at de assisterende teknologiene stort sett er mindre kontroversielle i dag, er at de har blitt brukt for å kompensere for redusert fertilitet (funksjonssvikt). Infertilitet har blitt oppfattet som en sykdom som trenger behandling. ${ }^{3}$

\section{Seleksjonsfremmende teknologier}

Det kanskje mest påtrengende moralske spørsmålet ved de ulike seleksjonsfremmende teknologiene er når det er riktig å drepe et foster ${ }^{4}$. Innbakt i dette ligger også spørsmål om hvilke tilstander som berettiger abort og hva som menes med «alvorlig sykdom» som berettiger abort.

Andre viktige og vanskelige spørsmål er: Hvem skal ha tilgang til hvilke typer tester? Hvor mye informasjon om fosteret skal den enkelte ha tilgang til? Når skal testene tas og når skal informasjonen være tilgjengelig, for eksempel i forhold til grensen for selvbestemt abort? Hvilke signaler sendes det til personer som har tilstander det søkes etter (og som selekteres bort)? Hvilke verdier fremmes gjennom offentlig støtte og gjennomføring av slike fravalg? Men også helt konkret: Er kjønnsseleksjon akseptabelt for familiebalansering?

PGD reiser mange av de samme fravalgsspørsmålene som fosterdiagnostikken reiser, men også et viktig tilvalgsspørsmål: Kan det være riktig å velge befruktede egg ut ifra bestemte egenskaper? I Norge (og mange andre land) er svaret på dette spørsmålet $j a$ i ett bestemt tilfelle: der det kan hjelpe et allerede sykt søsken gjennom at det nye barnet kan donere celler eller vev til sin syke søster eller bror, såkalt hjelpesøsken. I kjølvannet av dette, dukker det opp andre moralske spørsmål, som: For hvilke tilstander eller sykdommer skal det være tillatt med hjelpesøsken? ${ }^{5}$ For hvilke personer (søsken, foreldre, besteforeldre, venner)? Et spørsmål relatert til tilvalg, er om det er galt å sette inn befruktede egg som disponerer for sykdom hos fremtidig avkom. Ikke sjelden har man få befruktede egg å velge mellom, og man 
kan komme til å måtte velge mellom et befruktet egg som har en viss sjanse for å gi et barn som er bærer eller har sykdommen man vil unngå, og ingen egg. Skal man da sette inn det befruktede egget? Hvem tar man da i tilfelle (mest) hensyn til?

PGD reiser også et annet viktig spørsmål: Må de potensielle foreldrene selv ha (eller være bærere av) en tilstand for at de skal få benytte PGD? Personer med alvorlig sykdom i familien (slik som Huntingtons sykdom) kan ønske å få et barn som ikke vil få sykdommen, samtidig som de selv ikke vil teste seg for å få vite om de har eller vil få den. Dette kalles eksklusjonstesting, og er ikke tillatt ved PGD i Norge i dag.

Mange av de moralske spørsmålene som de seleksjonsfremmende teknologiene genererer, er altså knyttet til selve valget: innhold (abort), hva som skal velges (sykdom, tilstand, egenskap), hvem som skal velge og på vegne av hvem.

\section{Egenskapsendrende teknologier}

Tilsvarende reiser reproduktive teknologier som endrer egenskaper mange moralske spørsmål. Hvilke egenskaper er det rimelig å endre: Fare for sykdom? Hukommelse? Intelligens? Moralitet? Hvilket ansvar har vi når vi endrer grunnleggende menneskelige egenskaper, og hvordan skal vi ivareta ansvaret? Hvordan skal vi håndtere det at vi kan påvirke evolusjonen på langt mer effektive måter enn tidligere? At vi kan endre vår art?

I tillegg aktualiserer denne type teknologier spørsmålet om hva det vil si å være forelder. Med mitokondriedonasjon vil det kommende barnet få arvemateriale fra tre personer, og ifølge enkelte slektskapstester være i slekt med kvinnen som donerte egget (uten kjerne). I fremtiden vil man kunne «klippe inn» genmateriale fra mange personer eller redigere dette fritt. Hva vil det da si å være forelder? Hvilke rettigheter, plikter og bånd knytter det seg til de ulike former for foreldreskap? Er det ledende eller misvisende å bruke betegnelser som «mor» og «far»? Hvordan endres det sosiale presset for å bli genetisk og biologisk forelder? Finnes det moralsk relevante forskjeller på «morsrollene» og «farsrollene» i reproduksjonsprosessen og foreldreskapet? Vil fremtidige barn holde genregissøren ansvarlig for sitt vesen og sine handlinger?

Hvordan endres det allerede komplekse skillet mellom genetisk, biologisk og sosialt foreldreskap når barn kan få genetisk materiale fra flere enn to individer? Selv om det enda er noen år frem til dette blir konkrete valgmuligheter i klinikken, kan svar på dagens problemstillinger legge føringer for fremtidige svar. Mitokondriedonasjon tvinger oss derfor allerede nå til å reflektere over dette.

I tillegg vil egenskapsendrende teknologier gjøre det nødvendig på nytt å svare på moralske spørsmål om egenskaper («det gode liv»), om roller og om ansvar.

\section{Moralske sporsmål felles for reproduksjonsteknologier}

Teknologiene redegjort for i første del av artikkelen reiser også en rekke moralske spørsmål som er felles for flere av teknologiene. Jeg skal her kort nevne noen av disse: Hvem skal ha tilgang til teknologiene? Hvilke krav skal stilles til de som får tilgang til dem (fysisk, mentalt, sosialt)? Hvilke krav skal stilles til teknologien? Hvor effektiv skal den være? Hvor sikker skal den være? Hvem skal vurdere?

Et annet fellestrekk ved reproduksjonsteknologi er at den etablerer og endrer definisjonene av foreldreskap. IVF har etablert skillet mellom sosialt, biologisk og genetisk foreldreskap. «Genetisk mor» er betegnelsen på den som egget stammer fra. Som biologisk mor regnes den som føder barnet, og sosial mor er den som har 
omsorg for barnet og oppdrar det. Tilsvarende vil nye teknologier kunne bidra til nye former for foreldreskap. Hva skal vi kalle disse? Er de av det gode? For hvem?

All assistert reproduksjon gis som helsehjelp og forutsetter et uttrykkelig informert samtykke. Forutsetningen for et gyldig samtykke, er at personene har fătt og forstått relevant informasjon (Bunnik 2013; Faden 1991). Ved en rekke former for reproduksjonsteknologi kan det reises spørsmål om folk er godt nok informert om prosedyre, suksessrate og risiko. Har de forstått viktig og vanskelig informasjon om genetiske forhold (ved PGD og NIPT)? Hvordan skal man gi god informasjon om nytte, risiko og usikkerhet? Disse spørsmålene viser seg å være særlig relevante da ønskene om å få barn ofte er sterke og sammenfallende med interessene til de som tilbyr tjenestene. For enkelte former for reproduksjonsteknologi er suksessraten liten og risikoen betydelig (Ferraretti 2013; Traeger-Synodino 2013; Calhaz-Jorge 2016). Dette reiser også spørsmål om ansvar: Er det da riktig å overlate valget (og ansvaret) til paret? Hvilket ansvar har behandler? Hvilket ansvar har individet for å få barn i fertil alder? Hvilken rett har samfunnet til à begrense individers selvbestemmelse, og på hvilket grunnlag kan en slik begrensning forsvares? Er valgene frie eller er de gitt av press fra samfunnet og familien?

\section{Hvordan begrunne svarene? Grunnleggende etiske utfordringer}

Selv om mange av de moralske spørsmålene nevnt ovenfor har funnet sine løsninger i lover, forskrifter og i praksis, er enkelte fortsatt kontroversielle. Da fosterreduksjon nylig ble drøftet i Norge, ble det en svært opphetet debatt. Noe av grunnen til dette er at mange av de moralske spørsmålene som reproduksjonsteknologiene reiser, bunner i motstrid mellom grunnleggende etiske posisjoner eller prinsipper (antinomier) eller uløselige dilemmaer (aporier). La oss derfor se nærmere på enkelte slike grunnleggende etiske utfordringer, som gjør at de moralske spørsmålene ikke alltid finner stabile svar.

\section{Hvilken moralsk status har embryoer og fostre?}

Målet med assistert befruktning er å frembringe barn, og teknologiene anvendes på ulike forstadier til et menneske. Spørsmål om hvordan vi skal håndtere slike forstadier, herunder hvilke rettigheter og krav på beskyttelse det befruktede egget, embryoet og fosteret har, bunner i spørsmålet om moralsk status. Her er det i praksis mange motstridende syn. For enkelte har fosteret full moralsk status fra unnfangelsen, mens det for andre ikke har moralsk status før ved fødselen eller en stund etterpå. Eksempelvis har fosteret meget begrensede rettigheter i England, Belgia og Nederland, mens tysk lovgiving allerede tillegger det befruktede egget betydelig moralsk status. Den norske lovgivingen bygger i praksis på et graduelt syn på moralsk status, der fosteret har økende krav på beskyttelse ettersom det vokser.

Normativ tenkning, slik vi finner det i juss og etikk, har ikke tradisjon for å håndtere biologisk materiale eller potensielle personer (Parfit 1984). Å fastslå fostres moralske status representerer derfor en grunnleggende etisk utfordring som fortsatt ikke har funnet sin løsning. Moralsk status knyttes ofte til livssyn, mens spørsmålet om ansvar for fremtidige personer og generasjoner samt fostres rett til beskyttelse synes å berøre alle, uavhengig av livssyn. 


\section{Naturstridig eller evolusjonsfremmende?}

En annen grunnleggende utfordring er i hvilken grad naturen er normerende for våre handlinger. Spørsmålet om hvorvidt reproduksjonsteknologier er naturstridige bygger på en forståelse av at naturen gir normer for menneskelig atferd og inngripen. Også her finner vi mange motstridende syn. Mens enkelte oppfatter naturen som en gudgitt norm som ikke skal manipuleres, og andre ser den som en sårbar balanse som ikke må rokkes, ser atter andre naturen som et ufullstendig substratum som mennesket bør forbedre (Barilan 2001). ${ }^{6}$

En utfordring i debatter om naturens normer, er at naturbegrepet brukes ulikt. Nuffield Council on Bioethics har vist at «natur» brukes på minst fem forskjellige måter i offentlige debatter om teknologi og medisin (Nuffield Council on Bioethics 2015): Naturen er nøytral, representerer en visdom, har en essens og et formål, er trygg og vanlig og representerer en gudommelig orden. Når ulike naturbegreper brukes i samme debatter, blir de ofte uklare og lite konstruktive.

En annen utfordring i natur-baserte debatter om reproduksjonsteknologi, er at vi på så mange andre områder har «manipulert», «underlagt oss» og «kontrollert» naturen at det virker «unaturlig» å bruke naturbegrepet til å begrense reproduksjonsteknologi (Hofmann 2017). ${ }^{7}$

Moderne reproduksjonsteknologi er særlig interessant fordi den gjør abstrakte «natur-spørsmål» ubehagelig konkrete: Er det rett eller galt å sette inn befruktede egg som disponerer for sykdom hos fremtidig avkom? Er bruk av nedfryste egg og eggdonasjon fra yngre kvinner hos eldre kvinner egenskapsutvidende («human enhancement»)? Når det er vanskelig å gi konkrete svar på slike spørsmål, er det ofte fordi naturens normgivende funksjoner er uavklarte.

\section{Behandling eller forbedring?}

Utfordringen med naturens normbærende funksjon knytter an til en annen grunnleggende utfordring: Å skille mellom behandling og forbedring. I debatter om moderne bioteknologi vises det gjerne til dette skillet (Coady 2016), og det argumenteres med at bruk av bioteknologi til behandling er bra, mens bruk til forbedring er galt (Daniels 2000). Nedfrysing av kjønnsceller kan brukes i behandling av infertilitet, men også til å utvide fertilitet.

Forskjellen synes derfor nyttig for å skille mellom rett eller gal anvendelse og ikke mellom gode og dårlige teknologier. Problemet er bare at behandlingsbegrepet, slik vi bruker det i helsetjenesten i dag, allerede omfatter forbedring, og at skillet derfor oppfattes som kunstig (Coady 2016; Barilan 2001). Vi bruker jo både vaksine og prevensjon.

Å skille mellom behandling og forbedring volder både grunnleggende etiske og kunnskapsmessige utfordringer. Her er det vanskelig å komme til enighet.

\section{Sykdom eller skjebne?}

Tilsvarende har man forsøkt å bruke sykdomsbegrepet til å skille mellom rett og gal teknologianvendelse. Dersom reproduksjonsteknologien brukes til å behandle sykdom, så er den akseptabel. Ellers ikke. Også her møter vi etiske utfordringer: Er ufrivillig barnløshet en sykdom? Hvor alvorlig er infertilitet? Rammer den enkeltpersoner, par eller familier? Det som gjør det vanskelig å svare på disse spørsmålene er at infertilitet ikke kjennetegnes ved vanlige symptomer, omfatter flere personer og at behandlingen ikke er kurativ (White 1989). 
Grunnen til at skillet mellom sykdom og helse er viktig, er at sykdom påkaller en spesiell etisk fordring. Vi har en spesiell moralsk plikt til å hjelpe personer som lider av sykdom. Og moderne reproduksjonsteknologi gjør det abstrakte spørsmålet om sykdom konkret: Er risiko for å få barn med alvorlig sykdom en sykdom? Er fare for spontanabort en sykdom (ved PGD eller fosterdiagnostikk)? Hvem er pasienten ved PGD (den sykdomsbærende mannen, den friske kvinnen som behandles eller begge) $?^{8}$

Å besvare slike spørsmål med sykdomsbegrepet som mal hadde vært kjekt, men begrepet bygger selv på vanskelige verdivalg (White 1989; Hofmann 2014) og er fortsatt uavklart (Worrall 2001, Nordby 2004; Sadegh-Zadeh 2000).

\section{Foreldreskap}

Andre grunnleggende etiske utfordringer er knyttet til foreldreskap. Som allerede nevnt, konstituerer reproduksjonsteknologier ulike former for foreldreskap. I tillegg utfordrer den selve foreldrebegrepet. Når det er mulig å få barn med avdøde personer (ved nedfrosne kjønnsceller), når mitokondriedonasjon gjør at barn kan få genmateriale fra to (eller flere) kvinner eller når det er mulig å produsere kjønnsceller slik at to menn kan gi genetisk opphav til barn (ved omprogrammering av somatiske celler til eggceller og surrogati) (Hermerén 2010, Whittacker 2007; Newson 2005), så utfordres foreldrebegrepet som har vært normsettende i generasjoner, ikke minst for å fastslå ansvar for avkom. Prevensjon har frigjort sex fra reproduksjon. Reproduksjonsteknologi har i tillegg frigjort foreldreskap fra biologisk og/eller genetisk tilknytning. Ut over dette frigjør den fra partnerskap.

På samme måte som sentrale begreper, som natur, terapi og sykdom, er utfordret av reproduksjonsteknologi, utfordres også foreldrebegrepet og familiebegrepet (som har vært forholdsmessig stabile $\mathrm{i}$ årtusener). Grunnen til at dette volder etiske utfordringer er altså at foreldrebegrepet er knyttet til sosiale bånd og moralsk ansvar.

\section{Nytte og risiko}

I en tid dominert av nytteetisk tenkning, er det sentralt å kunne vurdere utbyttet av reproduksjonsteknologien. Selv om studier viser at nytten av å få barn (tilfredshet) er sterkt overvurdert (Angeles 2009; Dyrdal 2011) og at mange av dem som mislykkes med IVF likevel får barn (Johansson 2009), finnes det en rekke rapporter (og utallige fortellinger) om at bruk av reproduksjonsteknologi er til stor glede for veldig mange.

Suksessraten for assistert reproduksjon varierer mye (Traeger-Synodinos 2013; Harper 2010; Calhaz-Jorge 2016; Pandian 2005; Harper 2010; Myers 2008), og veldokumentert kunnskap om utbytte er begrenset (Whittaker 2007). For enkelte typer inseminering er suksessraten svært høy, mens for noen former for PGD er sannsynligheten for å få et friskt barn under $10 \%$.

Det er en rekke bivirkninger ved IVF-behandling, og pasienter har også dødd ved IVF-behandling i Norge. ${ }^{9}$ Der flere befruktede eggceller settes inn, er det i tillegg risiko knyttet til flerlingefødsel. ${ }^{10}$ Det kan også gi noe økt risiko for utviklingsavvik hos barnet ved assistert reproduksjon, men det er uklart om det skyldes metodene eller den underliggende årsaken til infertiliteten. Suksessraten (for å få barn) avtar med kvinnens alder, mens risikoen øker. Hvorvidt det bør settes en aldersgrense, og hvor den eventuelt bør gå, er omdiskuterte spørsmål. Det samme gjelder spørsmålet om hva som er akseptabel risiko for utviklingsavvik hos barnet (Hofmann 2003). 
Utfordringen er at grunnlaget for nytteetiske vurderinger er begrenset. Vi har knapt med kunnskap for å foreta velbegrunnede valg. Dette peker på et annet grunnleggende problem: selvbestemmelse.

\section{Selvbestemmelse}

Det er tre nødvendige betingelser for selvbestemmelse: 1) at man har forstått hva beslutningen omfatter, 2) at man har beslutningsevne og 3) at beslutningen er frivillig. Det viser seg at det kan være vanskelig å oppfylle disse vilkårene ved bruk av reproduksjonsteknologi (Lowe 2016).

Det er mange konkrete spørsmål som krever svar: Hvem skal bestemme hvor mange embryo som skal settes tilbake? Skal risiko- og nyttevurderingen og ansvaret overlates til de(n) enkelte, for eksempel ved vurderingen av alder? Hvilken rett har det kommende barnet til informasjon om seg selv (ved NIPT) eller sitt genetiske og biologiske opphav?

Selv om det i dagens samfunn legges stor vekt på selvbestemmelse, og særlig på reproduktiv selvbestemmelse, er autonomien i praksis begrenset, for eksempel i valget av hvilke tilstander det kan gjøres PGD eller tas abort for. I tillegg kan det oppstå konflikter mellom selvbestemmelsen til de ulike aktørene, herunder de som bidrar med (deler av) kjønnsceller eller det som skal bli til kjønnsceller, befruktede egg eller fostre, de som bringer frem barnet, barnet selv og profesjonelle.

\section{Ansvar}

Som vi har sett, reiser reproduksjonsteknologien også spørsmål om ansvar: Ansvar for utbytte (friske barn), for risiko og skade (på voksne og barn), for relasjoner mellom mennesker (foreldreskap, familie), men også for teknologi- og samfunnsutviklingen. Mens det ikke stilles krav til vordende foreldre ved unnfangelse uten medisinsk intervensjon, skal det i Norge gjøres en psykososial vurdering ved assistert befruktning (Bioteknologiloven 2003). ${ }^{11}$ Begrunnelsen for dette har vært at en medisinsk intervensjon medfører ansvar og at dette ansvaret også gjelder overfor det barnet som blir til ved assistert reproduksjon. Her står spørsmålet om hva som er barnets beste sentralt. Hvordan skal man vurdere egnethet hos fremtidige foreldre? Hvem skal vurdere egnetheten og hva som er bra for et fremtidig barn? Er alvorlig sykdom og tidlig død hos en av foreldrene skadelig for barnet? Når er man for gammel til å bli forelder? Hvilke krav skal stilles til samlivsform? Svarene på disse spørsmålene varierer i de nordiske landene (Soini 2015). Den underliggende utfordringen er å avklare ansvar for de ulike partene.

\section{Eugenikk}

Flere av de utfordringene som følger av moderne reproduksjonsteknologi er knyttet til vanskelige valg. Det spenner fra valg om hvilke befruktede egg som skal implanteres eller destrueres, til valg av hvilket foster som skal «reduseres» ved fosterreduksjon, hvilke tilstander som er alvorlige og uønskede (ved fravalg) og hvilke tilstander som er ønskede (ved hjelpesøsken, NIPT og endring av egenskaper). Er det eksempelvis legitimt å velge ut fostre slik at barn blir døve eller får lavere vekst («dvergvekst») (Savulescu 2009) for å få barn lik seg selv? Bør vi velge eller generere embryoer som gir økt intelligens, slik enkelte hevder (Moen 2016)? Valgene og utarbeidelse av kriterier som skal anvendes for slike valg representerer fundamentale utfordringer (Scott 2006; Hofmann 2008) og bunner i grunnleggende spørsmål om hva som er det gode liv, men også om eugenikk. ${ }^{12}$ 


\section{Signaleffekten}

I tillegg gir reproduksjonsteknologien utfordringer med hvilke normer som forsterkes eller skapes ved dens anvendelse. Jeg har allerede nevnt signaleffekten til personer som har de tilstandene som man systematisk søker og velger bort. Personer med slike tilstander kan føle seg fornærmet, krenket og diskriminert (Asch 1989; Parens 2000; Saxon 2000).

En tilstøtende og grunnleggende utfordring oppstår om summen av (legitime) individuelle valg strider med grunnleggende samfunnsmessige verdier - det som gjerne kalles det statsliberale dilemma (Nielsen 2003; Tennsjö 2008). Hvordan skal man i tilfelle balansere disse verdiene? Dette bunner i spenningen mellom in dividuelle og kollektive verdier.

De etiske utfordringene som er drøftet i denne delen av artikkelen har ingen enkle eller omforente løsninger. Det gjør at de moralske spørsmålene, som jeg drøftet i forrige del av artikkelen, ikke finner klare og stabile svar. Debattene blir derfor ofte heftige og uforsonlige - nærmest skyttergravsaktige. De kan finne pragmatiske svar, men blusser fort opp igjen. Derfor er det viktig å gjenkjenne disse grunnleggende etiske utfordringene i debatter om reproduksjonsteknologi - både for å forstå de ofte inkonsistente svarene som gis og deres midlertidighet, men også for å forstå hvorfor man ofte ikke kommer lenger i slike debatter. Å jobbe videre med disse etiske utfordringene er derfor viktige oppgaver for lek og lærd.

\section{De glemte sporsmålene}

I tillegg til de mange moralske spørsmålene som dukker opp i de heftige debattene om reproduksjonsteknologi, er det også en rekke sentrale spørsmål som ikke kommer frem. De er tabubelagte eller glemt. Jeg skal her kort løfte frem noen av disse.

Abortspørsmålet ligger under alle seleksjonsfremmende teknologier fordi fravalg foregår ved abort. Selv over 40 år etter abortstriden i Norge, er dette et så betent tema at det ikke diskuteres i offentligheten. ${ }^{13}$ Det er selvsagt mange grunner til det, men det gjør at den offentlige diskusjonen om mange reproduksjonsteknologier lett blir «betente» og lite konstruktive.

Et annet ikke-tema er adopsjon. Adopsjon er et åpenbart alternativ til alle former for reproduksjon som er drøftet i denne artikkelen. Helse- og omsorgsdepartementet har eksplisitt uttrykt at reproduksjonsteknologier ikke skal vurderes opp mot adopsjon, og offentlige midler brukt for å legge til rette for adopsjon er forsvinnende små sammenlignet med det som brukes på reproduksjonsteknologier. På samme måte som kvinner stiller opp som altruistiske surrogatmødre (i andre land), er det trolig at enkelte vil bære frem et barn for å la andre adoptere det istedenfor å fjerne fosteret, særlig når de vet at det ville glede dem enormt mye og at de vil ta godt vare på barnet. Adopsjon som alternativ til abort, blir imidlertid ikke omtalt eller drøftet. Vi kan bli spurt om å gi en nyre, men aldri en graviditet. ${ }^{14}$

Nært knyttet til adopsjonsspørsmålet er også spørsmålet om global rettferdighet. Det er i dag lite legitimt å spørre om det er riktig å bruke såpass mye ressurser på å frembringe fremtidige barn, når det er så mange eksisterende barn i verden som lider og dør (og som ikke har foreldre), og de samme ressursene kunne brukes til å gi disse et godt liv. 
Et annet spørsmål som synes glemt, er hvorvidt vi bør begrense den reproduktive friheten, og eventuelt hvordan? Den globale befolkningsveksten er stor og står ikke i forhold til økt matproduksjon og velstandsvekst. Det er ikke åpenbart at dagens utvikling er bærekraftig. Å overlate reproduksjon til den enkeltes valg kan synes lite fremtidsrettet. I tillegg øker manges levealder, og reproduktive teknologier kan øke fertiliteten. Man kan få flere barn over en lengre periode av livet. Hvordan livslengde skal avveies mot reproduktivitet er foreløpig et neglisjert spørsmål.

Det samme gjelder vurderingen av hvordan reproduktive behov skal avveies mot andre behov. Når vi i større grad intervenerer i reproduksjonen og de menneskelige egenskapene, må vi kanskje tenke annerledes om reproduksjon som et biologisk behov og om hvordan dette skal avveies mot andre behov og verdier. Kan vi vise til «behovet for å føre genene våre videre» når det ikke er «våre gener»? Det blir vanskeligere å vise til biologiske behov, når disse er endret. Dette synes oversett. Et annet glemt spørsmål er hvordan (reproduksjons)teknologier skaper sykdom. Mens ufrivillig barnløshet tidligere ble oppfattet som skjebne, har reproduksjonsteknologier gjort det til sykdom (Hofmann 2014). Hvilke nye sykdommer skapes av de teknologiene som er omtalt i denne artikkelen?

I tillegg blir følgende sjelden drøftet: «Hva er uønsket?» og «hva er alvorlig sykdom?» Og enda sjeldnere: «Hva er en god egenskap?» og «hva er et godt menneske?» Dette er helt sentrale spørsmål for moderne reproduksjonsteknologi.

Andre ting som sjelden blir vurdert, er rollen til det fremtidige barnet. Er det en person som drar nytte av tiltaket, og som derfor skal med i det nytte-etiske regnskapet? Eller skal referansen være at det vil fødes nok barn uansett, slik at gevinsten ikke kan sees uavhengig av den samlede befolkningen på jorden?

\section{Diskusjon}

Jeg har i denne artikkelen gjort rede for tre grupper av reproduksjonsteknologi og belyst en rekke av de moralske spørsmålene de reiser. I tillegg har jeg omtalt noen grunnleggende etiske utfordringer, som gjør at de moralske spørsmålene sjelden finner stabile og solide svar, men til stadighet blusser opp i til dels heftige offentlige debatter. Dette har jeg gjort for å forstå debattene bedre, men også for å erkjenne hvorfor vi ofte ikke kommer lenger - og hva vi må jobbe med. I tillegg har jeg pekt på moralske spørsmål som er glemt eller tabubelagte. Spørsmålene som vi ikke stiller kan fortelle oss like mye om oss selv og våre verdier, som de spørsmålene som drøftes eksplisitt. Dette er spørsmål vi fortrenger fordi de er ubehagelig å dvele ved (Zappfe 1943), og fordi vi har gjort midlene til mål og tapt målene av syne.

Reproduksjonsteknologienes etikk er svært omfattende, og til dels særdeles kompleks. På samme måte som ikke alle former for reproduksjonsteknologi har fått plass i denne artikkelen, har ikke alle moralske spørsmål og alle etiske utfordringer kommet med. Jeg har gjort et utvalg og kan selvsagt beskyldes for å være både selektiv i utvalget og skjev i presentasjonen. Dette er åpent for leseren å vurdere og kritisere.

Tilsvarende er det ikke plass til å referere til all relevant litteratur på feltet. Bare å gi en grundig og dekkende oversikt over de teknologiske mulighetene ville sprenge rammen for denne artikkelen. Mye mangler.

Dessuten er språket verdiladet. Vi har gått bort fra termer som «kunstig befruktning» og "prøverør» fordi de er ladede, men også dagens terminologi er verdiladet. Jeg unngår å bruke «sorteringssamfunnet», men bruker for eksempel 
betegnelsen «seleksjonsfremmende» ${ }^{15}$ som kan hevdes å være verdiladet. Det er vanskelig å fri språket om verdier for verdier. Også her må leseren gå meg etter i sømmene. Selv om språket ikke er nøytralt, har målet vært å presentere teknologien, spørsmålene og utfordringene på en måte som alle parter kan gjenkjenne.

Man kan også protestere mot å inndele teknologier for reproduksjons i tre typer: assisterende, selekterende og egenskapsendrende teknologier. Mange andre inndelinger kunne selvsagt vært brukt. Her er den valgt for å strukturere gjennomgangen og for å vise leseren noen viktige mønstre. Det er selvsagt også glidende overganger og overlapp mellom de tre typene reproduksjonsteknologi. For eksempel brukes PGD fertilitetsfremmende (assisterende) ved translokasjoner. ${ }^{16}$ Produksjon av kjønnsceller ved modifikasjon av hudceller kan også falle inn under flere av bolkene.

Man kan også innvende at grunnen til at de grunnleggende etiske utfordringene så sjelden drøftes og at noen moralske spørsmål neglisjeres, er at de er så vanskelige og at det ikke finnes noen omforente svar eller løsninger på dem. Det er selvsagt riktig, men det avdekker en underliggende tragisk dimensjon ved moderne reproduksjons-teknologi: Vi er blitt teknologiske helter som er fremragende på teknikk, men elendige på etikk. Mens vi er drivende dyktige til å utvikle reproduksjonsteknologier, er vi dårlige til å forutse, analysere og begrunne de moralske valgene de gir. Våre teknologiske visjoner er grandiose, men våre moralske innsikter beskjedne. Dermed synliggjøres også en tragisk dimensjon ved mennesket selv og vår gjøren i verden: Vi synes å være overutviklet når det gjelder teknologisk innovasjon, men ikke tilsvarende rustet for etisk refleksjon.

\section{Konklusjon}

Mulighetene for å frembringe barn og til å hjelpe mennesker til å få (friske) barn er mange. Som følge av at biologisk kunnskap og bioteknologi er i rivende utvikling, vil disse mulighetene eskalere. Og med dem vil de moralske spørsmålene vokse. I denne artikkelen har jeg forsøkt å peke på noen av de mest sentrale. I tillegg har jeg pekt på grunnleggende etiske utfordringer, som gjør at de moralske spørsmålene sjelden finner stabile og solide svar, men til stadighet blusser opp i til dels heftige offentlige debatter. Fosterets moralske status, naturlighet, behandling versus forbedring, sykdom versus helse, selvbestemmelse, ansvar, eugenikk og signaleffekt representerer noen slike etiske utfordringer.

Menneskers tilblivelse reiser grunnleggen de spørsmål om hva et menneske er, hva en forelder og familie er og hva det gode liv er. Aktiv inngripen i tilblivelsen av mennesker gir ansvar. Mange aktører og interessenter gjør problemstillingene uoversiktlige. Å ha kjennskap til de relevante moralske spørsmål og underliggende etiske utfordringer, kan hjelpe oss å forstå hvorfor vi ofte ikke kommer lenger - og hva vi må jobbe med for å kunne finne bedre og mer robuste svar. I tillegg må vi tørre å drøfte de glemte eller gjemte moralske spørsmålene, selv om det volder ubehag. Det vi ikke drøfter, forteller oss like mye om oss selv og våre verdier som de spørsmålene som drøftes eksplisitt. Dette må vi gjøre for å unngå å ende som den greske antikkens mest berømte tragiske helt, kong Ødipus. På samme måte som Ødipus gikk til grunne på grunn av sine beste egenskaper, står vi i fare for å gå til grunne på grunn av våre teknologiske evner, dersom vi som han ikke ser og reflekterer over vår moralske blindflekker før det er for sent. 


\section{Noter}

${ }^{1}$ Jeg skiller altså mellom moral (i betydningen hva som er rett å gjøre) og etikk (i betydningen hvordan moralske normer og verdier begrunnes). Dette skillet er ikke skarpt i dagligtale eller blant fagfilosofer. Her brukes det for å synliggjøre hvorfor reproduksjonsteknologi til stadighet skaper (uforsonlig) offentlig debatt.

${ }^{2}$ Dette forutsetter i dag bruk av surrogatmor.

3 En annen viktig grunn er at når teknologier blir legalisert, så blir de institusjonaliserte, for deretter å bli normaliserte. Se for eksempel Kristin Clemet, Morgenbladet 21.10.2016.

${ }^{4}$ I offentlig debatt virker denne betegnelsen ofte provoserende, men det er allment akseptert i den filosofiske debatten at provosert abort er drap av biologisk liv (foster). Det moralsk relevante spørsmålet er når et slikt drap er rett eller galt. Jeg tillater meg her å bruke den filosofiske betegnelsen. Jeg er selvsagt klar over at enkelte mener at det aldri er rett å drepe fostre, mens andre mener det alltid er rett å gjøre det og at begge disse gruppene mener at spørsmålet om «når det er rett ...» er feil stilt.

${ }^{5}$ Må tilstandene være genetisk betingede (slik at hjelpesøskenet selv har «nytte av PGD»)? Hvor alvorlig må de være?

6 Zapffe har her et poeng med at naturen ikke gir mening etter «åndens gjennomstråling av Universet som livets mål og mening» (1943).

${ }^{7}$ På samme måte som respiratorer og andre former for medisinsk teknologi har gjort det vanskelig å definere $d ø d$, gjør moderne reproduksjonsteknologi det vanskelig å definere naturlig reproduksjon.

${ }^{8}$ Dette er ikke teoretiske spørsmål, men konkrete utfordringer ved alvorlig arvelig sykdom og kromosomavvik: Ved PGD for kromosomavvik blir risiko for spontanabort regnet som sykdom og ved "PGD for å utelukke alvorlig, arvelig sykdom hos det kommende barn, foreligger det ingen pasient"(Ot.prp. nr. 26 (2006-7): 62).

${ }^{9}$ Siren Skrede, personlig meddelelse.

${ }^{10}$ Praksis i Norge er at det vanligvis settes inn ett embryo.

${ }^{11}$ Se også Utkast til rundskriv 2006, der dette er godt gjort rede for.

${ }^{12}$ Eugenikk stammer fra gresk «av god avstamning» og refererer til arvehygiene. Mens termen har hatt en negativ betydning på grunn nazistenes eugenikk under 2. verdenskrig, argumenterer flere i dag for en ny og positiv eugenikk som følge av de nye teknologiske mulighetene.

${ }^{13}$ Et konstruktivt unntak er en debatt mellom Marianne Mjåland og Willy Pedersen i Morgenbladet i sommeren 2008.

${ }^{14}$ Igjen, så kan det finnes gode grunner til dette, men fordi de aldri når den offentlige debatten, har grunnene liten betydning i norm- og verdidannelsen i samfunnet.

15 Dette fordi det er enklere enn «teknologier som muliggjør seleksjon av kjønnsceller, befruktede egg og embryoer».

${ }^{16}$ Hovedproblemet er ikke at translokasjonene gir stor sannsynlighet for at det skal fødes et barn med alvorlig sykdom, men at (affiserte) fostre (spontan)aborteres og at det er vanskelig for paret å få barn. PGD brukes da for å velge ut befruktede egg som har redusert sannsynlighet for spontanabort, altså assisterende. 


\section{Litteratur}

Angeles, L. (2009) Children and life satisfaction. Journal of Happiness Studies, 11(4), s. 523-538. https://doi.org/10.1007/s10902-009-9168-z

Asch, A. (1989) Reproductive Technology and Disability. I: S. Cohen \& N. Taub, (red). Reproductive Laws for the 1990s. Clifton, N.J.: Humana Press, 69-124. https://doi.org/10.1007/978-1-4612-3710-5_4

Bioteknologinemnda. (2007) Assistert befruktning til par der mannen har Klinefelters syndrom. Brev fra Bioteknologinemnda til Sosial- og helsedirektoratet, 11.09.2007. http://www.bion.no/filarkiv/2010/07/ 2007_09_11_klinefelter_svarbrev_til_shdir.pdf (Besøkt 26.04.2012)

Barilan, Y. M., \& Weintraub, M. (2001). The naturalness of the artificial and our concepts of health, disease and medicine. Medicine, Health Care and Philosophy, 4(3), 311-325. https://doi.org/10.1023/A:1012034826744

Baruch, E.H., Amadeo, A.D'A. \& Seager J. (1988) Embryos, ethics and womens rights: Exploring the new Reproductive technologies. New York: Haworth Press.

Bunnik, E. M., Jong, A., Nijsingh, N., \& Wert, G. M. (2013). The new genetics and informed consent: differentiating choice to preserve autonomy. Bioethics, 27(6), 348-355. https://doi.org/10.1111/bioe.12030

Buster, J.E., Bustillo, M., Thorneycroft, I.H., et al. (1983) Non-surgical transfer of in vivo fertilized donated ova to five infertile women: report of two pregnancies. Lancet, 2, s. 223-224. https://doi.org/10.1016/S0140-6736(83)90208-8

Calhaz-Jorge, C., de Geyter, C., Kupka, M., de Mouzon, J., Erb, K., Mocanu, E., . . . Goossens, V. (2016). Assisted reproductive technology in Europe, 2012: results generated from European registers by ESHRE. Human Reproduction, dew151.

Chen, S. C., \& Wasserman, D. T. (2017). A Framework for Unrestricted Prenatal Whole-Genome Sequencing: Respecting and Enhancing the Autonomy of Prospective Parents. The American Journal of Bioethics, 17(1), 3-18. https://doi.org/10.1080/15265161.2016.1251632

Clark, A.T. (2010) Egg-citing advances in generating primordial germ cells in the laboratory. Biol Reprod, 82(2), s. 233-4. https://doi.org/10.1095/ biolreprod.109.082388

Coady, T., Sanyal, S., \& Giubilini, A. (2016). The Ethics of Human Enhancement: Understanding the Debate: Oxford University Press.

Cohen, J., Scott, R., Schimmel, T. et al. (1997) Birth of infant after transfer of anucleate donor oocyte cytoplasm into recipient eggs. Lancet, 350(9082), s. 961-2. https://doi.org/10.1016/S0140-6736(05)63305-3

Craven, L., Tuppen, H.A., Greggains, G.D., et al. (2010) Pronuclear transfer in human embryos to prevent transmission of mitochondrial DNA disease. Nature 465(7294), s. 82-85. https://doi.org/10.1038/nature08958

Cutas, D., Dondorp, W., Swierstra, T., Repping, S., \& de Wert, G. (2014). Artificial gametes: perspectives of geneticists, ethicists and representatives of potential users. Medicine, Health Care and Philosophy, 17(3), s. 339-345. https://doi.org/10.1007/s11019-013-9535-8

Cutas, D., \& Smajdor, A. (2016). "I am Your Mother and Your Father!" In Vitro Derived Gametes and the Ethics of Solo Reproduction. Health Care Analysis, s. 1-16. https://doi.org/10.1007/s10728-016-0321-7

Daniels, N. (2000). Normal functioning and the treatment-enhancement distinction. Cambridge Quarterly of Healthcare Ethics, 9(03), 309-322. https://doi.org/10.1017/S0963180100903037 
Deng, J.M., Satoh, K., Chang, H., et al. (2010) Generation of Viable Male and Female Mice from Two Fathers. Biol Reprod. http://www.biolreprod.org/ content/early/2010/12/07/biolreprod.110.088831.long (Besøkt 10.01.2012)

Dyrdal, G.M., Røysamb, E., Nes, R.B., et al. (2011) Can a happy relationship predict a happy life? A population-based study of maternal well-being during the life transition of pregnancy, infancy, and toddlerhood. J Happiness Stud (Epublisering) http://www.springerlink.com/content/n46l37k75u742604/ fulltext.pdf (Besøkt 10.01.2012).

Eggan, K., Rode, A., Jentsch, I., et al. (2002) Male and female mice derived from the same embryonic stem cell clone by tetraploid embryo complementation. Nat Biotechnol, 20(5), s. 455-9. https://doi.org/10.1038/nbt0502-455

Faden, R. (1991). Autonomy, Choice, and the New Reproductive Technologies: The Role of Informed Consent. Women and New Reproductive Technologies: Medical, Psychosocial, Legal, and Ethical Dilemmas, 37.

Ferraretti, A., Goossens, V., Bhattacharya, S., Castilla, J., de Mouzon, J., Korsak, V., . . . Kupka, M. (2013). O-090 assisted reproductive technology in Europe, 2010. Human Reproduction, 28(suppl_1), i38-i39.

Fredriksen, S. (2006). Tragedy, utopia and medical progress. J Med Ethics, 32(8), 450-453. https://doi.org/10.1136/jme.2005.013292

Hamzelou, J. (2016). Exclusive: World's first baby born with new 3 parent technique. New Scientist, 27.

Harper, J.C., Coonen, E., De Rycke, M., Harton, G., Moutou, C., Pehlivan, T., Traeger-Synodinos, J., Van Rij, M.C. \& Goossens, V. (2010) ESHRE PGD Consortium data collection X: cycles from January to December 2007 with pregnancy follow-up to October 2008. Hum Reprod, 25(11), s. 2685-707. https://doi.org/10.1093/humrep/deq228

Hendriks, S., Dancet, E. A. van Pelt, A. M. Hamer, G. \& Repping, S. (2015). Artificial gametes: a systematic review of biological progress towards clinical application. Human reproduction update, 21(3), s. 285-296. https://doi.org/ 10.1093/ humupd/dmv001

Hermerén, G. (2010) Barn från hudceller - ett framtida alternativ till surrogatmödraskap? Läkartidningen, 107(44), s. 2696-7.

Hofmann, B. (2003) Technology assessment of intracytoplasmic sperm injection (ICSI) - an analysis of the value context. Fertil Steril, 80(4), s.930-5. https://doi.org/10.1016/S0015-0282(03)01152-X

Hofmann, B. (2005) On value-judgements and ethics in health technology assessment. Poiesis \& Praxis: International Journal of Technology Assessment and Ethics of Science, 3(4), s. 277-295. https://doi.org/10.1007/s10202-0050073-1

Hofmann, B. (2008) Selektive utfordringer ved assistert befruktning for personer med Klinefelter syndrom. Etikk i praksis Nordic Journal of Applied Ethics, 2(1), s. 69-85. https://doi.org/10.5324/eip.v2i1.1690

Hofmann, B. (2014) Hva er sykdom? Oslo: Gyldendal akademisk.

Hofmann, B., \& Moldestad, O. (2012). Assistert reproduksjon - biologi og etikk. Tidsskr Nor Legeforen, 132(7), 856-859. https://doi.org/ 10.4045/tidsskr.11.1505

Hofmann, B. (2017). Limits to human enhancement: nature, disease, therapy or betterment. BMC Meical Ethics, 18(56), 1-11. https://doi.org/10.1186/s12910017-0215-8 
Hübner, K., Fuhrmann. G., Christenson, L.K., et al. (2003) Derivation of oocytes from mouse embryonic stem cells. Science, 300(5623), s. 1251-6. https://doi.org/10.1126/science.1083452

Innst. O. nr. 16(2003-2004) om bioteknologiloven.

Lowe, P. (2016). Reproductive health and maternal sacrifice: women, choice and responsibility. London: Springer. https://doi.org/10.1057/978-1-137-47293-9

Johansson, M., Adolfsson ,A., Berg, M., Francis, J., Hogström, L., Janson, P.O., Sogn, J. \& Hellström, A.L. (2009) Quality of life for couples 4-5.5 years after unsuccessful IVF treatment. Acta Obstet Gynecol Scand, 88(3), s. 291-300. https://doi.org/10.1080/00016340802705956

Ma, H., Marti-Gutierrez, N., Park, S.-W., Wu, J., Lee, Y., Suzuki, K., . . Ahmed, R. (2017). Correction of a pathogenic gene mutation in human embryos. Nature, 548(7668), s. 413-419. https://doi.org/10.1038/nature23305

Moen, O. M. (2016). Bright New World. Camb Q Healthc Ethics, 25(2), 282-287. https://doi.org/10.1017/S0963180115000584

Myers, E.R., McCrory, D.C., Mills, A.A. et al. (2008) Effectiveness of assisted reproductive technology (ART). Evid Rep Technol Assess, (167), s. 1-195.

Nagano, M.C. (2007) In vitro gamete derivation from pluripotent stem cells: progress and perspective. Biol Reprod, 76(4), s. 546-51. https://doi.org/ 10.1095/biolreprod.106.058271

Nayernia, K., Nolte, J., Michelmann, H.W., Lee, J.H., Rathsack, K., Drusenheimer, N., et al. (2006) In vitro-differentiated embryonic stem cells give rise to male gametes that can generate offspring mice. Dev Cell, 11(1), s. 125-32. https://doi.org/10.1016/j.devcel.2006.05.010

Newson, A.J., Smajdor, A.C. (2005) Artificial gametes: new paths to parenthood? J Med Ethics, 31, s. 184-186.

Nielsen, T.H. (2003). Bioteknologi - et dilemma for det liberale samfunn. Aftenposten 13.06.2003.

Nordby, H. (2004). En enhetlig eller en mangfoldig forstaelse av sykdom? Tidsskr Nor Laegeforen, 124(2), 201-202.

Nuffield Council on Bioethics. (2015). Ideas about naturalness in public and political debates about science, technology and medicine. London, http://nuffieldbioethics.org/project/naturalness/the-findings/ (Besøkt 20.12.2016)

Ohinata, Y., Ohta, H., Shigeta, M., et al. (2009) A signaling principle for the specification of the germ cell lineage in mice. Cell, 137(3), s. 571-84. https://doi.org/10.1016/j.cell.2009.03.014

Palermo, G., Joris, H., Devroey, P., et al. (1992) Pregnancies after intracytoplasmic sperm injection of single spermatozoon into an oocyte. Lancet, 2, s. 17-8. https://doi.org/10.1016/0140-6736(92)92425-F

Pandian, Z., Gibreel, A.F. \& Bhattacharya, S. (2005) In vitro fertilisation for unexplained subfertility. Cochrane Database of Systematic Reviews, Issue 2. Art. No.: CD003357. https://doi.org/10.1002/14651858.CD003357.pub2

Parens, E., Asch, A., (2000) Prenatal Testing and Disability Rights. Washington, D.C.: Georgetown University Press.

Parfit, D. (1984) Reasons and persons. Oxford: Oxford University Press.

Bioteknologiloven av 2003, $2-6$.

Regalado, A. (2016, 04.04.). Chinese Researchers Experiment with Making HIVProof Embryos. MIT Technology Review. 
Sadegh-Zadeh, K. (2000). Fuzzy health, illness, and disease. J Med Philos, 25(5), 605-638. https://doi.org/10.1076/0360-5310(200010)25:5;1-W;FT605

Savulescu, J., \& Kahan, G. (2009) The moral obligation to create children with the best chance of the best life. Bioethics 23 (5), s. 274-290. https://doi.org/ $10.1111 / j .1467-8519.2008 .00687 . x$

Scott, R. (2006) Choosing between possible lives: legal and ethical issues in preimplantation genetic diagnosis. Oxf J Leg Stud, 26(1), s. 153-78. https://doi.org/10.1093/ojls/gqi048

Soini, S. (2015) Legislation on biotechnology in the Nordic countries. Oslo: NordForsk.

Steptoe, P.C., \& Edwards, R.G. (1978) Birth after the reimplantation of a human embryo. Lancet, 2, s. 366. https://doi.org/10.1016/S0140-6736(78)92957-4

Tachibana, M., Sparman, M., Sritanaudomchai, H., et al. (2009) Mitochondrial gene replacement in primate offspring and embryonic stem cells. Nature, 461(7262), s. 354-5. https://doi.org/10.1038/nature08368

Takahashi, K., Tanabe, K., Ohnuki, M., et al. (2007) Induction of pluripotent stem cells from adult human fibroblasts by defined factors. Cell, 131(5), s. 861-72. https://doi.org/10.1016/j.cell.2007.11.019

Takahashi, K., \& Yamanaka, S. (2006) Induction of pluripotent stem cells from mouse embryonic and adult fibroblast cultures by defined factors. Cell, 126(4), s. 663-76. https://doi.org/10.1016/j.cell.2006.07.024

Tannsjö, T. (2008) Procreative liberty or collective responsibility. XVIII Nordic IVF Meeting, Oslo, Proceedings,18, s.17-18.

Toyooka, Y., Tsunekawa, N., Akasu, R., et al. (2003) Embryonic stem cells can form germ cells in vitro. Proc Natl Acad Sci USA 100(20), s. 11457-62. https://doi.org/10.1073/pnas.1932826100

Traeger-Synodinos, J., Coonen, E., Goossens, V., De Mouzon, J., Shenfield, F., Ruiz, A., . . . de Mouzon, J. (2013). Session 09: ESHRE data reporting on PGD cycles and oocyte donation. Human Reproduction, 28(suppl 1), i18-i19. https://doi.org/10.1093/humrep/det162

Trounson, A, Mohr, L. (1983) Human pregnancy following cryopreservation, thawing and transfer of an eight-cell embryo. Nature, 305, s. 707-9. https://doi.org/10.1038/305707a0

Utkast til rundskriv om medisinske og psykososiale vurderinger av par som søker assistert befruktning. Helsedirektoratet. Oversendt til HOD i januar 2006.

Vassena, R., Heindryckx, B., Peco, R., Pennings, G., Raya, A., Sermon, K., \& Veiga, A. (2016). Genome engineering through CRISPR/Cas9 technology in the human germline and pluripotent stem cells. Hum Reprod Update, 22(4), s. 411419. https://doi.org/10.1093/humupd/dmw005

White, G.B. (1989) Ethical analysis in the development of congressional public policy. J Med Philos, 14 (5), s. 575-585. https://doi.org/10.1093/jmp/14.5.575

Whittaker, P. (2007) Stem cells to gametes: how far should we go? Human Fertility, 10(1), s. 1-5. https://doi.org/10.1080/14647270600883234

Worrall, J., \& Worrall, J. (2001). Defining Disease: Much Ado about Nothing? In A.-T. Tymieniecka \& E. Agazzi (Eds.), Life Interpretation and the Sense of Illness within the Human Condition (Vol. 72, pp. 33-55): Springer Netherlands. https://doi.org/10.1007/978-94-010-0780-1_3

Zapffe, Peter Wessel. (1943/1996) Om det tragiske. Oslo: Universitetsforlaget. 
Zhang, J., Zhuang, G., Zeng, Y., Grifo, J., Acosta, C., Shu, Y., \& Liu, H. (2016). Pregnancy derived from human zygote pronuclear transfer in a patient who had arrested embryos after IVF. Reprod Biomed Online, 33(4), 529-533. https://doi.org/10.1016/j.rbmo.2016.07.008 